\section{Trialkyl lead in rain in the Black Forest}

SIR-We have recently suggested that high concentrations of trialkyl lead, $\mathrm{R}_{3} \mathrm{~Pb}^{+}$, as detected, for example, in rainwater samples from the Black Forest, may be harmful to the forests of Central Europe'. The theory has been seriously questioned by M.H. Unsworth and R.M. Harrison ${ }^{2}$. We wish to provide some new and supplementary data, which we believe can help to remove their doubts.

The most serious questions posed by the authors concerned the bioassay used for quantitation of $\mathrm{R}_{3} \mathrm{~Pb}^{+}$. In continuing our study for several months of this year on behalf of the government of BadenWürttemberg, two independent methods have been employed for the determination of $\mathrm{R}_{3} \mathrm{~Pb}^{+}$in rain water. In addition to the tubulin assay, all samples were submitted to a chemical separation procedure which was also used for the determination of some of the concentration values cited by Unsworth and Harrison. The results of both assays were the same within the limits of experimental error. Again, four of the samples collected at two locations in the Black Forest had trialkyl lead concentrations higher than $0.2 \mu \mathrm{M}$

Unsworth and Harrison were concerned about the likelihood of the occurrence of such high concentrations of $\mathrm{R}_{3} \mathrm{~Pb}^{+}$ in rain. The concentrations are indeed 100-1,000 times higher than those reported by others. So far, however, analytical data on trialkyl lead in rain are scarce. The few data known are from locations with a typical sea climate, which may not be comparable to locations on the Continent. Moreover, the occurrence of trialkyl-lead-polluted rain seems to be confined to small areas, as shown by the analytical results obtained from one of our sampling stations which, although located only $100 \mathrm{~km}$ east of the Feldberg, has never given $\mathrm{R}_{3} \mathrm{~Pb}^{+}$values above the limit of detection. Sampling at this site alone would have led to different conclusions. Finally, the Antwerp data mentioned by Unsworth and Harrison were one-sample measurements, and therefore statistically insignificant. In 1984, it took us 4 months of uninterrupted observation before we recorded a single toxic event.

Unsworth and Harrison argue that the low concentrations of $\mathrm{R}_{3} \mathrm{~Pb}^{+}$in the atmosphere cannot account for the high concentrations of $\mathrm{R}_{3} \mathrm{~Pb}^{+}$in rain. For the undegraded compound $\mathrm{R}_{+} \mathrm{Pb}$, Harrison and coworkers reported atmospheric concentrations at rural sites of up to $230 \mathrm{ng} \mathrm{m}^{-3}$. After degradation, the distribution of $\mathrm{R}_{3} \mathrm{PbX}$ can be expected to remain unchanged, at least for some period of time. However, values of $\mathrm{R}, \mathrm{PbX}$ were reported to be as low as $2 \mathrm{ng} \mathrm{m}^{-3}$. So where is the rest? The loss is most easily explained by the high instability of salts when dispersed in air. They may be captured by polar media, such as surfaces of particulate matter, and would therefore be analysed together with the inorganic lead. Indeed, in most of the studies of atmospheric lead pollution, the term "inorganic lead" stands for the lead fraction removed by filters. $\mathrm{R}_{3} \mathrm{PbX}$ could be washed off the surface of such particles, on contact with rain or fog. In our example, $230 \mathrm{ng}$ of $\mathrm{R}_{3} \mathrm{PbX}$ would be dissolved in about $10 \mathrm{ml}$ $\left(10 \mathrm{~g} \mathrm{~m}^{-3}\right.$ is the typical atmospheric humidity in Europe). The resulting concentration would be about $10^{-7} \mathrm{M}$, which is within the range of $\mathrm{R}_{3} \mathrm{PbX}$ found in the Black Forest. This value does not consider the $\mathrm{R}_{3} \mathrm{PbX}$ that may be taken up by rain on its way from clouds to the surface.

Fortunately, we do not disagree on controversial theories but on a finding that can be examined experimentally. Therefore, we suggest that further discussion should be postponed until our results have been confirmed by others. Twin samples were taken of most of the rainwater samples collected in 1985 in the Black Forest. They are waiting to be analysed.

H. Faulstich

C. Stournaras

Man-Planck-Institut für Medizinsche

Forschung,

D-6900 Heidelberg 1 ,

Postfach 1038 20, FRG

Faulstich, H. \& Stournaras, C. Nature 317, 714-715 (1985) Unsworth, M.H. \& Harrison. R.M. . Nature 317, 674 (1985) De Jonghe. W.R.A. Van Mol. W.E. \& Adams, FC Analyt. Chem. 55, 1050)-1054 (1983).

Birch, J. Harrison, R.M. \& Laxen, D.P.H. Sci. Tot. Envir 14. $31-42$ (1980)

\section{An anniversary for the lipid bilayer}

SiR-The year 1985 marked the sixtieth anniversary of the proposal by Gorter and Grendel' that biological membranes consist of a double layer of lipid molecules, as appropriately mentioned by Bretscher ${ }^{2}$. In $1925 \mathrm{E}$. Gorter, a pediatrician with a strong interest in chemical pathology, and F. Grendel, a chemist in the laboratory of the University Children's Hospital at Leiden, The Netherlands, derived their cell membrane model from observations made with rather simple experimental techniques. The lipid extracted with ace-

\section{Scientific Correspondence}

Scientific Correspondence is intended to provide a forum in which readers may raise points of a rather technical character which are not provoked by articles or letters previously published (where the Matters Arising section remains appropriate) tone from a known amount of erythrocytes was spread as a monolayer on a water surface. The ratio of monolayer lipid area to total erythrocyte surface turned out to be close to $2: 1$ for red blood cells from different mammalian species. Thus the investigators concluded with the suggestion that in the cell membrane of erythrocytes sufficient lipid is present for constituting a molecular bilayer. The structural model is the more remarkable because it was derived without any modern instrumental method such as infrared spectrometry, gas chromatography or electron spin resonance. Already 10 years ago, the Gorter-Grendel model was considered by Bretscher and Raff $^{3}$ a major breakthrough in cell biology, comparable to that of the double DNA helix. In 1934 Danielli and Davson improved on the model by allowing for proteins to be additional components of plasma membranes. The fluid mosaic model proposed in 1972 by Singer and Nicolson ${ }^{5}$, viewing functional biological membranes as bidimensional solutions of integral proteins in a liquid phospholipid matrix, remains the current basis for experimental work.

In 1966, Bar et al. ${ }^{6}$ repeated the GorterGrendel experiments and discovered two major errors. First, acetone treatment extracts membrane lipids, and cholesterol in particular, incompletely. Second, more refined measurements of the surface area of the human erythrocyte yield the value of $145 \pm 8 \mu^{2}$ instead of $99 \mu^{2}$, the value used in 1925. The Dutch investigators had in fact made two mutually compensating errors of about $40 \%$.

We are proud that in 1935 Dr E.Gorter, at that time chairman of the pediatrics department at Leiden, accepted an invitation from Ghent State University to come and found the first university children's hospital in Flanders, Belgium. The strong interaction between pediatric observation and biochemical research, kindled by Professor Gorter, and promoted continually by his pupil and successor, Professor Hooft, who died in 1980 , remedied effectively the developmental delay of pediatrics in Belgium. We owe much to Evert Gorter, who was once called: 'The best chemist among all pediatricians and the best pediatrician among all chemists.'

\section{J.A. KINT \\ J.G. LEROY}

Department of Pediatrics, State University of Ghent, De Pintelaan 185, B-9000, Ghent, Belgium

Gorter, E. \& Grendel. F. J. Exp. Med. 41, 439-444. (1925) Bretscher. M.S. Scientific American 253, 86-92. (1985) Bretscher. M.S. \& Raff. M.C. Nature 258, 43-49. (1975) 4. Danielli. J.F. \& Davson. H.J. J. cell. Comp. Physiol. 5, 495-508. (1934)

Singer S J. \& Nicolson. G I Science 174, 720-728, (1972) 6. Bar. R.S.. Deamer. D.W. \& Cornwell. D.G. Science 153, 1010-1012. (1966) 